\title{
High-Resolution 3D Reconstruction Reveals Intra-Synaptic Amyloid Fibrils
}

\author{
Estibaliz Capetillo-Zarate, ${ }^{*}$ Luis Gracia, ${ }^{\dagger}$ \\ Fangmin Yu, ${ }^{*}$ Jason R. Banfelder, ${ }^{\dagger}$ \\ Michael T. Lin, ${ }^{*}$ Davide Tampellini, ${ }^{* \neq}$ and \\ Gunnar K. Gouras* \\ From the Department of Neurology and Neuroscience," and the \\ HRH Prince Alwaleed Bin Talal Bin Abdulaziz Alsaud Institute \\ for Computational Biomedicine, ${ }^{\dagger}$ Weill Cornell Medical College, \\ New York, New York; and the Department of Experimental \\ Medical Science, ${ }^{\ddagger}$ Wallenberg Neuroscience Center, Lund \\ University, Lund, Sweden
}

$\beta$-Amyloid (A $\beta$ ) accumulation and aggregation are hallmarks of Alzheimer's disease (AD). High-resolution three-dimensional (HR-3D) volumetric imaging allows for better analysis of fluorescence confocal microscopy and $3 D$ visualization of $A \beta$ pathology in brain. Early intraneuronal $A \beta$ pathology was studied in AD transgenic mouse brains by HR-3D volumetric imaging. To better visualize and analyze the development of $A \beta$ pathology, thioflavin $S$ staining and immunofluorescence using antibodies against $\mathbf{A} \beta$, fibrillar $\mathrm{A} \beta$, and structural and synaptic neuronal proteins were performed in the brain tissue of Tg19959, wild-type, and Tg19959-YFP mice at different ages. Images obtained by confocal microscopy were reconstructed into three-dimensional volumetric datasets. Such volumetric imaging of CA1 hippocampus of $\mathrm{AD}$ transgenic mice showed intraneuronal onset of $\mathrm{A} \beta 42$ accumulation and fibrillization within cell bodies, neurites, and synapses before plaque formation. Notably, early fibrillar $A \beta$ was evident within individual synaptic compartments, where it was associated with abnormal morphology. In dendrites, increasing intraneuronal thioflavin $S$ correlated with decreases in neurofilament marker SMI32. Fibrillar A $\beta$ aggregates could be seen piercing the cell membrane. These data support that $\mathrm{A} \beta$ fibrillization begins within $\mathrm{AD}$ vulnerable neurons, leading to disruption of cytoarchitecture and degeneration of spines and neurites. Thus, HR-3D volumetric image analysis allows for better visualization of intraneuronal $A \beta$ pathology and provides new insights into plaque formation in AD. (Am J Pathol 2011, 179:2551-2558; DOI: 10.1016/j.ajpath.2011.07.045)
$\beta$-Amyloid $(A \beta)$ accumulation is a pathological hallmark of Alzheimer's disease (AD), and during the past decade there has been increasing evidence for a critical role for the accumulation of $A \beta$ within neurons in AD. Many studies have shown early intraneuronal $A \beta 42$ accumulation in $A D$, Down syndrome, and familial Alzheimer's disease (FAD) mutant transgenic rodents. ${ }^{1-18}$ Importantly, in a triple transgenic mouse, intraneuronal $A \beta$ accumulation was the earliest pathological correlate of abnormalities in long-term potentiation and behavior. ${ }^{19,20}$ Thioflavin $S$ (ThS)-positive intraneuronal $A \beta$ fibrils have been described in both APPSLPS1KI and 5XFAD transgenic mice. ${ }^{21,22}$ Moreover, neuron loss correlated with the prior appearance of ThS-positive intraneuronal $A \beta$ fibrils in transgenic mice. ${ }^{22}$ By immunoelectron microscopy, A $\beta 42$ normally localizes to endosomal vesicles. A $\beta 42$ increases with aging, particularly at the outer membranes of multivesicular bodies and smaller endosomal vesicles, and particularly in distal processes and synaptic compartments, where such $A \beta$ accumulation can be directly associated with ultrastructural pathology. ${ }^{6,23}$

The development of new imaging software allows for higher resolution image analysis of immunofluorescence confocal microscopy. Volume-rendering techniques display two-dimensional stacks of images as 3D volumetric images. High-resolution three-dimensional (HR-3D) volumetric image analysis provides a more complete 3D view of $A \beta$ pathology, leading to new insights into neurite and synapse disruption. In the present study, we provide HR-3D evidence for intracellular $A \beta$ accumulation and fibrillization within synapses, and distal and proximal processes of neurons in CA1 hippocampus. These images demonstrate that before the onset of plaque pathology, intraneuronal $A \beta$ accumulation and fibrillization can de-

This research was supported by grants from the National Institutes of Health (AG027140 and AG028174 to G.K.G., and AG20729 to M.T.L.), and the Strong Research Environment Multipark (Multidisciplinary research in Parkinson's disease at Lund University).

Accepted for publication July 19, 2011.

Supplemental material for this article can be found on http://ajp. amjpathol.org or at doi: 10.1016/j.ajpath.2011.07.045.

Address reprint request to Gunnar K. Gouras, M.D., Wallenberg Neuroscience Center, Department of Experimental Medical Science, Lund University, Lund, Sweden. E-mail: gunnar.gouras@med.lu.se. 
velop within soma, dendrites, and even within individual spines, with disruption of synaptic and neuritic cytoarchitecture. These new data support that intraneuronal $A \beta$ provides the nidus for plaque formation.

\section{Materials and Methods}

\section{Antibodies}

Mouse monoclonal antibody $\mathrm{G} 2-13$ recognizes the C-terminus of $A \beta 42$ (Millipore, Billerica, MA). Rabbit polyclonal antibody OC (Millipore) recognizes epitopes common to fibrillar $A \beta$ species, but not nonfibrillar oligomers or natively folded proteins, as characterized biochemically and morphologically by Kayed et al. ${ }^{24}$ We used ThS to visualize amyloid fibrils. Antibody SMI32 reacts to a nonphosphorylated epitope in neurofilament $\mathrm{H}$ and visualizes neuronal cell bodies, dendrites, and some thick axons in the central and peripheral nervous systems; thin axons are not labeled (Convance, Princeton, NJ). Mouse monoclonal antibody NeuN specifically recognizes a DNAbinding, neuron-specific protein. NeuN protein distribution is restricted to neuronal nuclei, perikarya, and some proximal processes (Millipore). Vesicular glutamate transporter-1 (VGlut1) guinea pig antibody recognizes glutamatergic synaptic vesicles (Millipore). Postsynaptic density 95 (PSD-95) antibody specifically recognizes the PSD-95 protein located in postsynaptic terminals of excitatory synapses (Santa Cruz Biotechnology, Santa Cruz, CA).
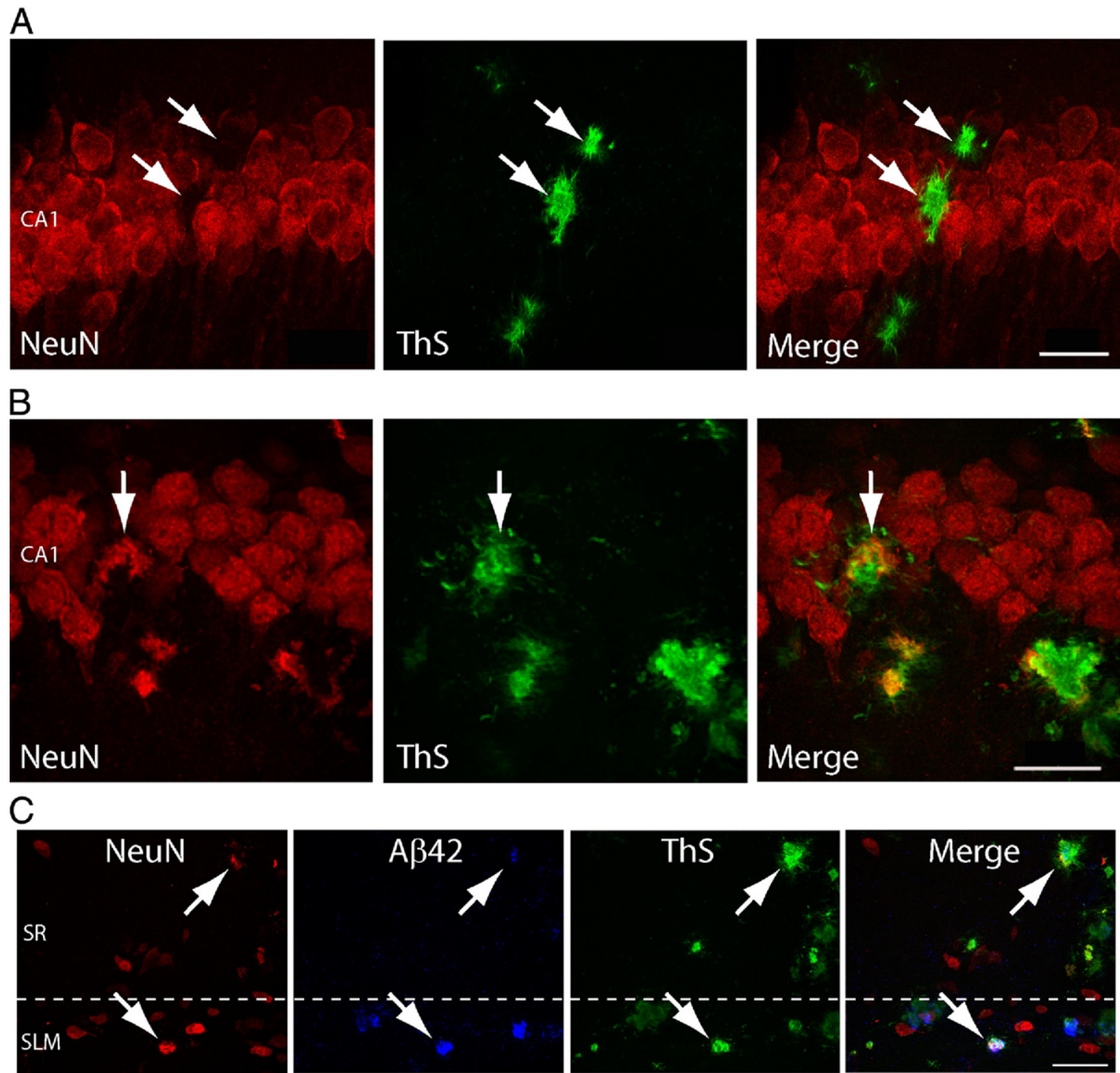

Figure 1. Thioflavin $S$ (ThS) positive plaques colocalize with neuronal marker NeuN in CA1 hippocampus. A: The 5-month-old Tg19959 mouse reveals Ths (green) positive $\beta$-amyloid $(\mathrm{A} \beta$ ) plaques within the $\mathrm{CA} 1$ pyramidal cell body layer. At this age, areas that are labeled with ThS (arrows) are near but not directly colabeled with neuronal marker NeuN (red; arrows). B: In contrast, ThS and NeuN colocalize (merged arrows) in the CA1 pyramidal cell body layer in 3-month-old Tg19959 mice. C: Colocalization (arrows) of ThS, A $\beta 42$ (blue), and NeuN is also seen in synaptic layers of the hippocampus, stratum radiatum, and stratum lacunosum moleculare in 3-month-old Tg19959 mice, supporting that GABAergic interneurons are also a site of ThS positive A $\beta$ fibrils. Scale bars: $25 \mu \mathrm{m}$ $(\mathbf{A}, \mathbf{B}), 50 \mu \mathrm{m}(\mathbf{C})$. Animations of the high-resolution three-dimensional reconstructions (B, C) are shown in Supplemental Videos S1 and S2 (available at http://ajp.amjpathol.org), respectively. 


\section{Animals}

All mouse experiments were compliant with the requirements of the Institutional Animal Care and Use Committee of Weill Cornell Medical College and with the National Institutes of Health guidelines. Tg19959 mice were obtained from Dr. George Carlson (McLaughlin Research Institute, Great Falls, MT). These mice contain human APP695 with two familial AD mutations (KM670/671NL and V717F) under the control of the hamster PrP promoter. ${ }^{25}$ Hemizygous male Tg19959 mice were bred to female Thy1.2-YFP-H homozygotes ${ }^{26}$ to produce double hemizygous Tg19959/YFP-H mice in the F1 generation. Animals were screened for the presence of the human APP695 and Thy 1.2-YFP-H transgenes by PCR. Brain sections from Tg19959 $(n=6)$, wild-type $(n=6)$, Tg19959-YFP $(n=3)$, and YFP $(n=3)$ mice were analyzed.

\section{Immunohistochemistry}

Mice were anesthetized with intraperitoneal pentobarbital and perfused transcardially with saline followed by $4 \%$ paraformaldehyde in 0.1 M PBS $(\mathrm{pH} \mathrm{7.4)}$ at room temperature. After dissection, brains were postfixed by immersion in $4 \%$ paraformaldehyde in $0.1 \mathrm{M} \mathrm{PBS}(\mathrm{pH} 7.4)$ at $4^{\circ} \mathrm{C}$ for 2 hours or overnight. After fixation, brains were cut in 40 - or $100-\mu \mathrm{m}$ thick sections with a vibratome. Sections were kept in storage buffer composed of $30 \%$ sucrose and $30 \%$ ethylene glycol in PBS at $-20^{\circ} \mathrm{C}$. Free-floating sections were first incubated in primary antibodies for 24 hours at room temperature, followed by appropriate fluorescent Alexa secondary antibodies (1:200; Molecular Probes, Eugene, OR) for 1 hour at room temperature. For dual and triple label ThS staining, sections were incubated in $0.001 \%$ ThS in $70 \%$ ethanol for 20 minutes, and then rinsed sequentially with $70 \%, 95 \%$, and $100 \%$ ethanol after immunofluorescent labeling.

\section{Imaging}

Images were collected using a Leica SP5 spectral confocal microscope (Leica Microsystems, Inc., Buffalo Grove, IL) equipped with HeNe 633 nm/HeNe 543 nm/ Argon (458, 476, 488, $514 \mathrm{~nm}$ ) lasers and with an HCX PL APO CS 63x/NA1.4 oil objective. Two-dimensional images obtained by confocal microscopy were reconstructed into 3D volumetric datasets using Avizo software (Visualization Science Group, Burlington, MA). Isosurfaces were defined individually for each channel from the raw confocal data and rendered as semi-opaque, solid surfaces. During data visualization and exploration, volumetexture visualizations were also used to better appreciate the continuum of intensities in each channel throughout the dataset. This technique computes the opacity and color of each voxel in the 3D volume as a function of the intensities of both channels. Visualization parameters for both isosurface and volume textures were optimized to highlight relevant neuronal structures and pathologies. Movie animations were generated from the Avizo software (Visualization Science Group) to highlight features of interest and to visualize the three-dimensionality of the datasets.

\section{Quantification}

Colocalization of $A \beta 42$ with synapses labeled with preVGlut1 or PSD-95 markers from confocal acquired images was determined by using a colocalization algorithm (Leica Application Suite 1.8.2 software), which shows only pixels with relative colocalization.

\section{Statistical Analysis}

Statistical comparisons were made using the Student's $t$-test with significance placed at $P<0.05$. Data were expressed as mean \pm SEM. Statistical analysis was performed using Excel (Microsoft, Redmond, WA).
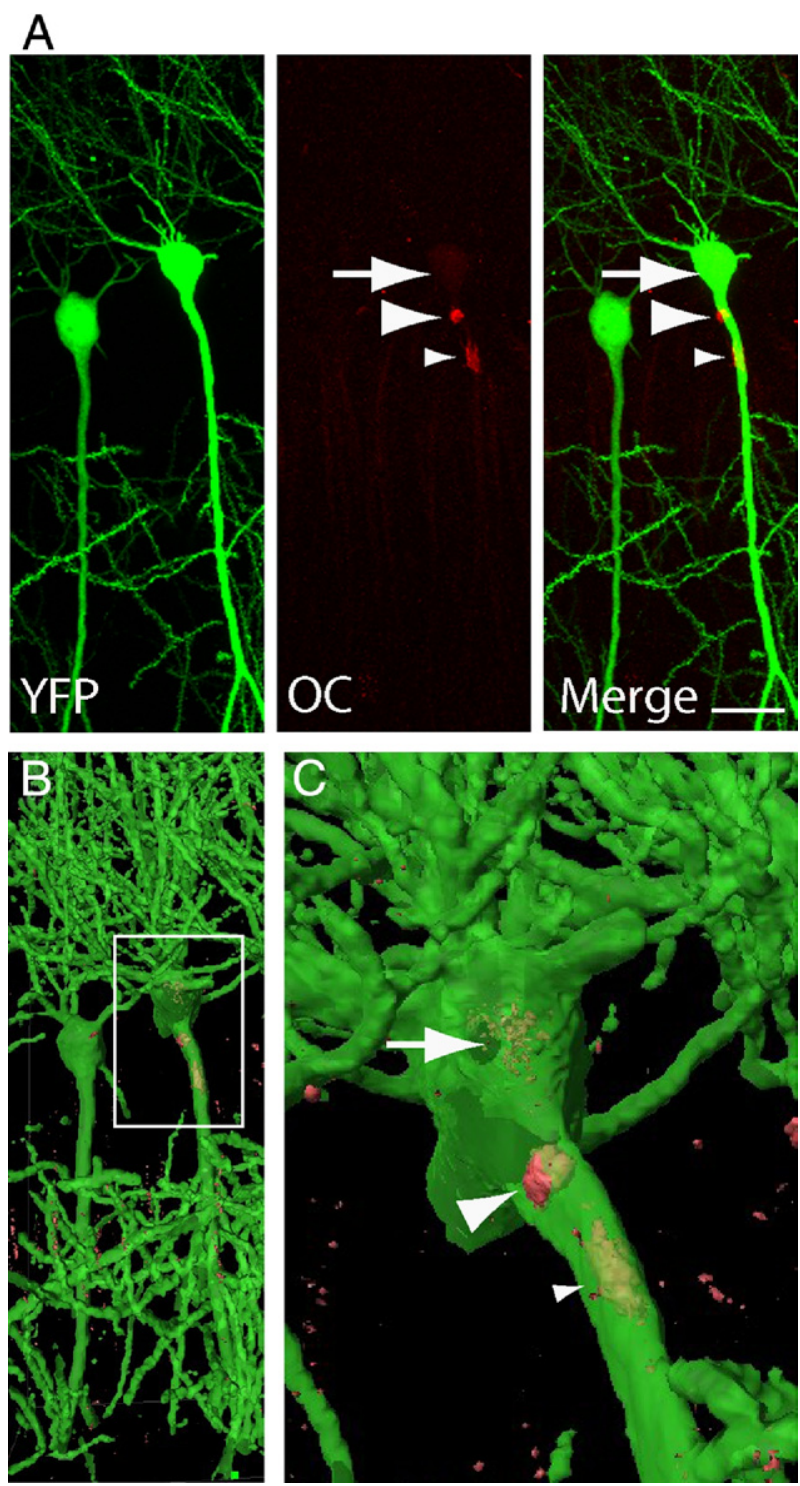

Figure 2. Early intracellular fibrillar $\beta$-amyloid (A $\beta$ ) species within soma and proximal processes of pyramidal neurons of CA1 hippocampus in Tg19959YFP mouse brain. A: OC antibody immunofluorescence reveals fibrillar A $\beta$ species in the cell body (arrow) and in proximal areas of apical dendrites (green; arrowheads), where at times they are seen piercing the cell membrane (large arrowhead). B: High-resolution three-dimensional (HR-3D) surface representation of $(\mathbf{A})$. C: Higher magnification of boxed area in $\mathbf{B}$ more clearly shows intracellular OC labeling (arrows). Scale bar: $20 \mu \mathrm{m}$ (A). Animation of the HR-3D reconstruction is shown in Supplemental Video S3 (available at http://ajp.amjpatbol.org). 


\section{Results}

High-Resolution 3D Volumetric Images

Demonstrate Amyloid Fibrils within Neuron Cell Bodies in CA1 Hippocampus

Tg19959 mice over-express double FAD mutant (KM670/671NL and V717F) human APP695 and exhibit plaque formation between 2 and 3 months. ${ }^{25}$ At 4 months of age these mice show spatial memory deficits and reduced levels of synaptophysin. ${ }^{27}$ At 5 months of age, when these mice show marked $A \beta$ pathology, we noted that some $A \beta$ plaques were located within the CA1 pyramidal cell body layer of the hippocampus. Double labeling with a neuronal marker (NeuN) and ThS at this age showed ThS-positive $A \beta$ plaques within
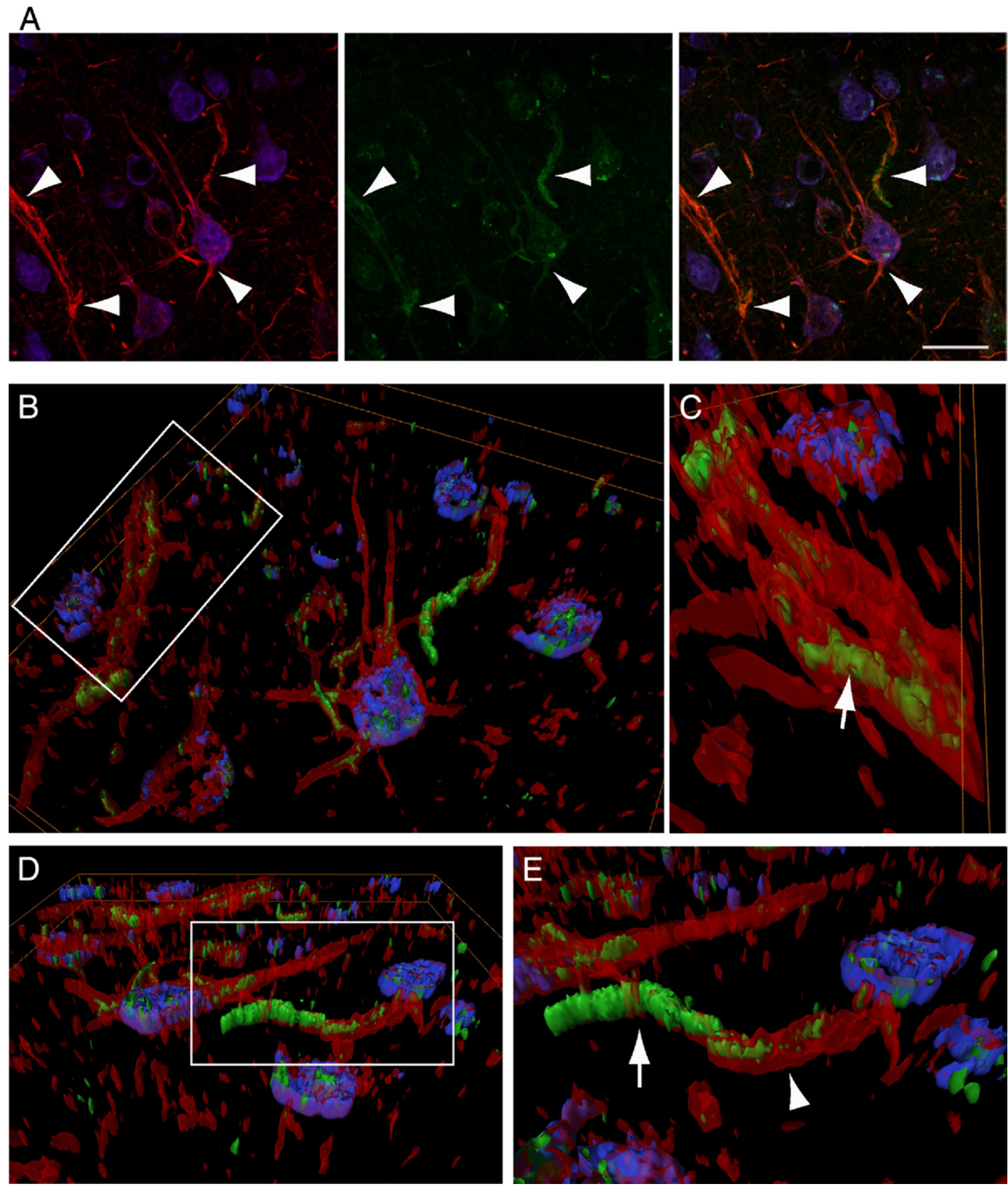

Figure 3. Intraneuritic fibrillar $\beta$-amyloid $(\mathrm{A} \beta$ ) disrupts the cytoarchitecture of dendrites in Tg19959 mice. A: Intracellular thioflavin $S$ (ThS)-positive staining (green) is seen in selective pyramidal neuron cell bodies (blue; NeuN) and neurites (red; arrowheads). B: High-resolution three-dimensional (HR-3D) surface representation of (merged $\mathbf{A}$ ). C: Rear view of the selected area in (B) shows intracellular ThS-positive staining within a SMI32-positive neurite (red; arrow). D: View from another angle of the surface representation of (A). E: Higher magnification of the box in (D) highlights that increasing ThS staining (arrow) in a neurite correlates with reduced neurofilament SMI32 labeling intensity (arrowhead). Scale bar $=25 \mu \mathrm{m}$ (A). Animation of the HR-3D reconstruction is shown in Supplemental Video S4 (available at http://ajp.amjpathol.org) 
the CA1 pyramidal neuron cell body layer. At this late age, with $A \beta$ appearing in extracellular plaques, there was no direct overlap of ThS with the neuronal marker NeuN (Figure 1A).

To examine whether $A \beta$ plaque-like deposits in CA1 arose from neuron cell bodies, we studied these mice at an earlier stage of plaque pathology at 3 months of age. At this earlier age, HR-3D images now showed colocalization of ThS and NeuN in the CA1 hippocampal pyramidal cell body layer of Tg19959 mice (Figure 1B) (see Supplemental Video S1 at http://ajp.amjpathol.org), supporting that $A \beta$ fibrils are within $C A 1$ neurons at this time. To examine whether ThS and NeuN dual-labeling also occurred outside the CA1 pyramidal cell body layer, we examined the CA1 stratum radiatum and stratum lacunosum moleculare. Neuron populations located in these CA1 hippocampal areas are GABAergic interneurons. Triple labeling of 3-month-old Tg19959 mice revealed colocalization of ThS, $\mathrm{A} \beta 42$, and NeuN in these layers as well (Figure 1C) (see Supplemental Video S2 at http://ajp.amjpathol.org). These data support that at least some $A \beta$ fibrils arise from neuron cell bodies, including glutamatergic pyramidal neurons and GABAergic interneurons, of CA1 hippocampus in Tg19959 transgenic mice.

\section{Fibrillar A $\beta$ Species Occur Early within Neurons and Can Traverse the Cell Membrane}

To focus on an even earlier stage in the progression of $A \beta$ pathology, we analyzed Tg19959 mice at 2 months of age, which is just before the onset of $A \beta$ plaque pathology in these mice. To better study morphological alterations in neurons and their processes, we crossed

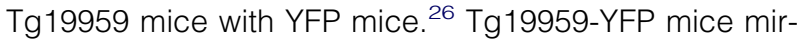
ror the $A \beta$ pathology of Tg19959 mice and also contain a subset of neurons that are YFP labeled, including cell bodies, axons, dendrites, and spines. These mice do not show ThS positive $A \beta$ plaques at 2 months of age, and therefore we used antibody OC, which has been shown to detect $A \beta$ fibrillar species, as characterized biochemically and morphologically by Kayed et al. ${ }^{24}$ It should be noted that the characterization of these different $A \beta$ species and their conformations is complex, and moreover that characterization of antibody binding in vitro may not necessarily reflect binding in vivo in the brain. With these caveats in mind, we used antibody $\mathrm{OC}$ as a marker for $\mathrm{A} \beta$ fibrillar species. It has been described that $\mathrm{OC}$ detects fibrillar $A \beta$ species in the absence of ThS staining, ${ }^{24}$ which we also confirmed (see Supplemental Figure S1 at http://ajp.amjpathol.org). We found OC antibody labeling
A

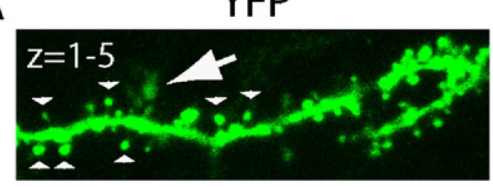

B
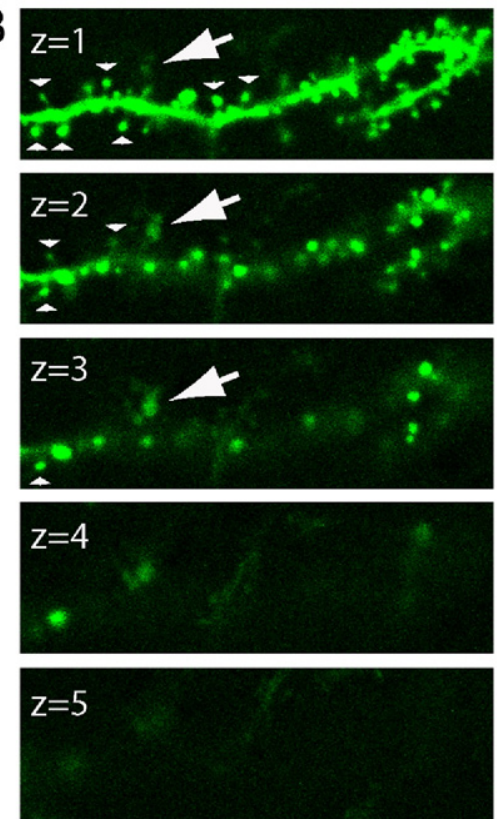
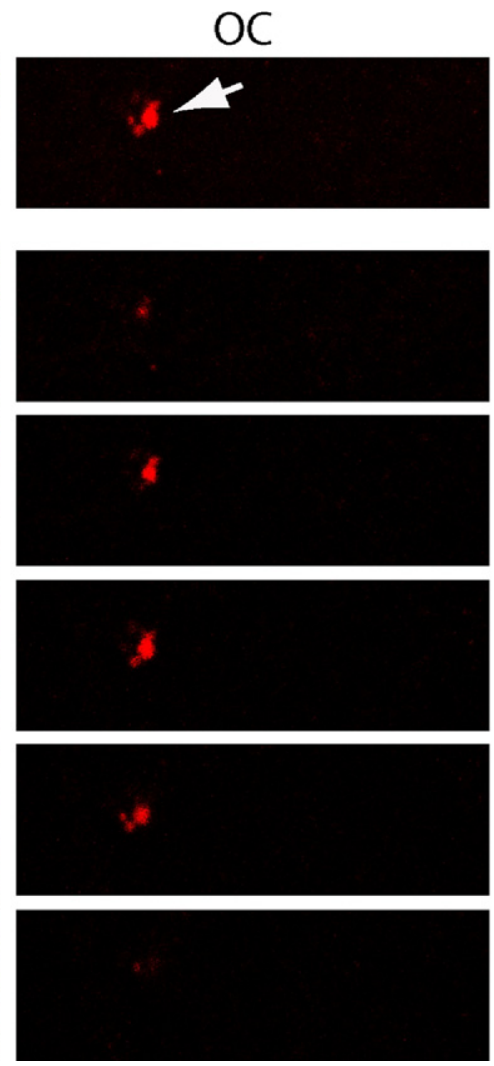
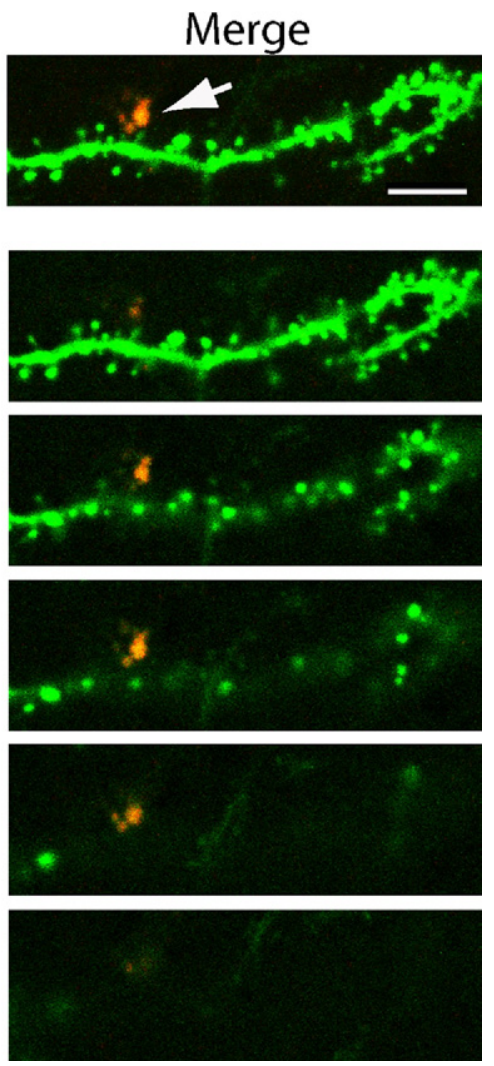

Figure 4. Early intracellular fibrillar $\beta$-amyloid $(\mathrm{A} \beta)$ species within individual spines in CA1 stratum radiatum. A: Merged image shows the colocalization of OC labeling fibrillar A $\beta$ species (red) with YFP (green) within an individual spine in a dendrite of a 2-month-old Tg19959-YFP mouse (arrow). The representative image shows dystrophic enlargement of the spine with intracellular fibrillar A $\beta$ accumulation compared to spines without fibrillar $\mathrm{A} \beta$ accumulation (arrowheads). The image represents a two-dimensional projection of a stack of five consecutive images. B: Sequence of individual images shown in (A). OC negative spines are mostly mushroom shaped and can be located near the OC-positive spine showing dystrophic elongation of the spine head and neck and more diffuse YFP staining. Scale bar $=4 \mu \mathrm{m}$ (A). Animation of the high-resolution three-dimensional reconstruction is shown in Supplemental Video S5 (available at bttp://ajp.amjpatbol.org). 
in the 2-month-old Tg19959 mice, which were negative for ThS. At 2 months of age, before formation of ThS plaques, OC antibody immunofluorescence colocalized with YFP in proximal and distal processes of pyramidal CA1 neurons in Tg19959-YFP mice (Figure 2A) (see Supplemental Video S3 at http://ajp.amjpathol.org). HR-3D isosurface representation clearly showed that OC antibody labeling was intraneuronal (Figure 2, B and C). For example, fibrillar $A \beta$ species could be seen in the cell body and proximal CA1 apical dendrites. In some HR-3D isosurface images, $O C$ positive fibrillar $A \beta$ species were even seen traversing the plasma membrane of neurites (Figure $2 \mathrm{C}$ ).

\section{Amyloid Fibrils also Occur within Neurites and Disrupt their Cytoarchitecture}

To examine whether intracellular $A \beta$ accumulation and fibrillization disrupts the cytoarchitecture of neurites, brain sections of 3-month-old Tg19959 mice were colabeled with ThS, neurofilament specific antibody SMI32, and NeuN. We note that ThS is not evident in wild-type mouse brain using these methods (data not shown). HR-3D fluorescence imaging clearly showed the intraneuronal onset of $A \beta$ fibrillization in processes of Tg19959 mouse brains (Figure 3) (see Supplemental Video S4 at
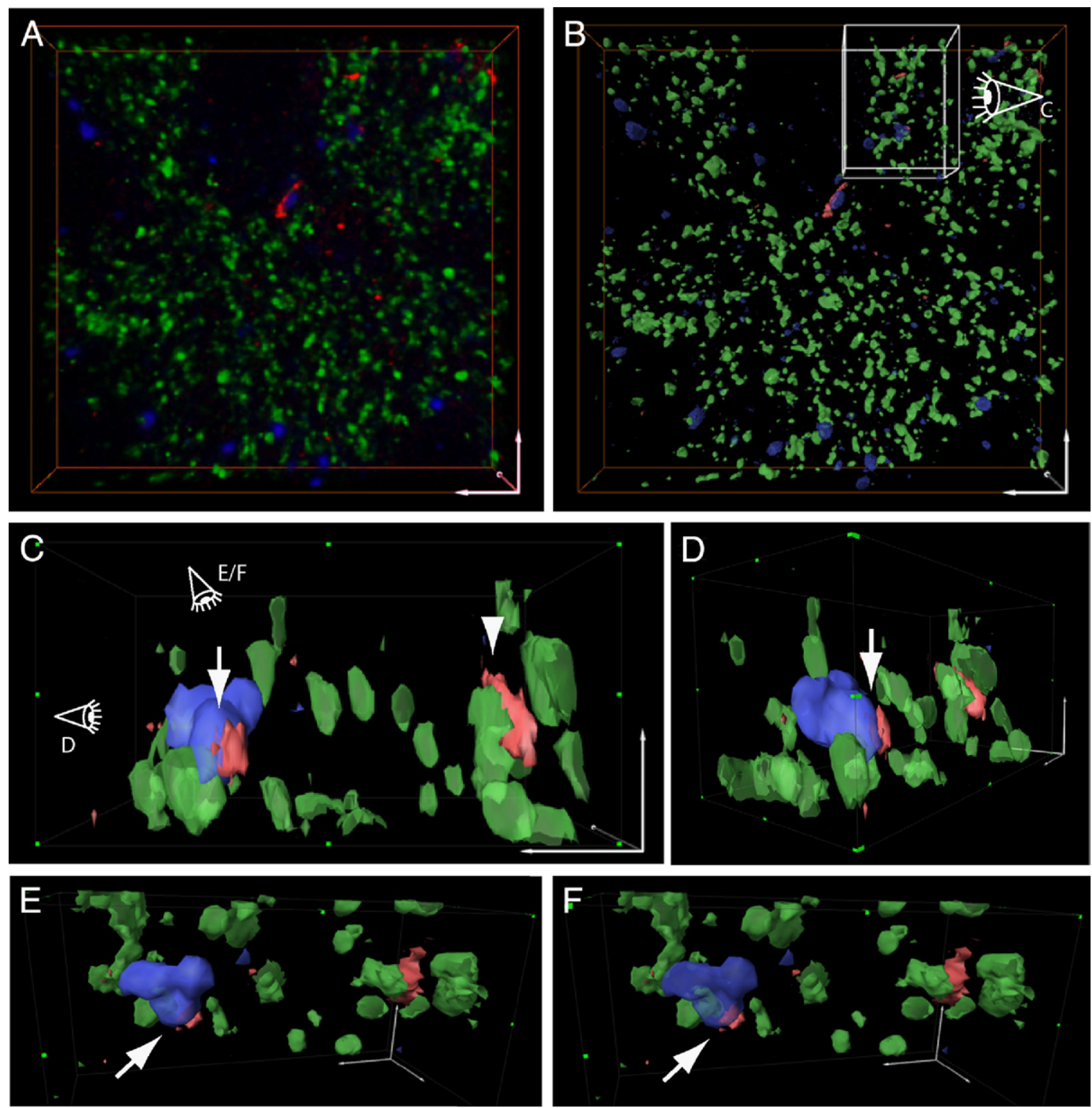

Figure 5. Fibrillar $\beta$-amyloid (A $\beta$ ) within postsynaptic terminals in Tg19959 mice visualized by the high-resolution three-dimensional (HR-3D) surface representation. A: Three-dimensional representation of a stack of images of a section with triple immunofluorescence labeling with vesicular glutamate transporter-1 (VGlut1) (green), postsynaptic density 95 (PSD-95) (blue), and OC (red) antibodies. B: HR-3D surface representation of (A) provides better visualization of synapses. C: Side view of the selected area in (B). OC antibody labeling shows fibrillar A $\beta$ piercing the PSD-95 positive (arrow) compartment adjacent to a glutamatergic pre-synaptic terminal (arrowhead). D: Side view of $(\mathbf{C})$ shows postsynaptic intraneuronal fibrillar A $\beta$ (E, F). Both images show top views of $(\mathbf{C})$. $\mathbf{E}$ and $\mathbf{F}$ show intracellular fibrillar $\mathrm{A} \beta$ within the postsynaptic compartment (arrows). In (F), surface representation intensity of PSD-95 labeling is set to be more transparent than in (E) to more clearly show the intracellular localization of OC labeling. Scale bars: $3 \mu \mathrm{m}(\mathbf{A}, \mathbf{B}), 1 \mu \mathrm{m}(\mathbf{C}-\mathbf{F})$. Animation of the HR-3D reconstruction is shown in Supplemental Video S6 (available at http://ajp.amjpathol.org). 
http://ajp.amjpathol.org) now revealed that increasing intracellular ThS staining intensity correlated with decreasing intraneuronal SMI32 neurofilament labeling.

\section{Fibrillar A $\beta$ Species Occurring within Individual Spines Can Penetrate the Cell Membrane and Are Associated with Dystrophy}

Next we focused on whether $A \beta$ accumulation preferentially occurred in presynaptic or postsynaptic compartments of different CA1 hippocampal synaptic layers (see Supplemental Figure S2 at $h$ ttp://ajp.amjpathol.org). At 2 months of age, Tg19959 mice showed $50 \pm 5 \%$ colocalization of $A \beta 42$ and PSD-95 in the stratum lacunosum moleculare and $52 \pm 3 \%$ in the stratum radiatum. Colocalization of $A \beta 42$ with the glutamatergic pre-synaptic marker VGlut 1 was $28 \pm 2 \%$ in the stratum lacunosum moleculare and $13 \pm 2 \%$ in the stratum radiatum. These data indicate that before the onset of plaque pathology, $A \beta 42$ accumulated more in postsynaptic compared to presynaptic terminals of CA1 hippocampus.

Remarkably, we noted that OC-positive fibrillar A $\beta$ species could be located within individual postsynaptic terminals before the onset of $A \beta$ plaque pathology in 2-month-old Tg19959-YFP mouse sections. Intracellular OC labeling was evident within individual spines in CA1 stratum radiatum (Figure 4) (see Supplemental Video S5 at $h$ ttp://ajp.amjpathol.org). OC-negative spines tended to show mainly a mushroom shape compared to OC-positive spines, which showed dystrophic enlargement of the spine head and neck. Interestingly, OC-positive and OCnegative spines could be located in close proximity on the same dendrite. Dystrophic OC-positive spines also showed more diffuse YFP labeling compared to the OCnegative spines with intense YFP labeling.

To further examine this synaptic localization of $A \beta$ fibrillar species at a later time point, we co-labeled 3-month-old Tg19959 mouse sections with VGlut1, PSD-95, and OC antibodies. HR-3D surface representations of immunofluorescent-labeled sections showed OC immunoreactivity clearly associated with synapses and within synaptic compartments. Intracellular OC labeling was particularly evident within PSD-95 labeled postsynaptic compartments and also could be seen traversing the cell membrane (Figure 5) (see Supplemental Video S6 at $h$ ttp://ajp.amjpathol.org).

\section{Discussion}

Many aspects of the origin of plaques and the pathogenic role of $A \beta$ in $A D$ remain unclear. ${ }^{28}$ Although the $A \beta$ hypothesis has posited that extracellular $A \beta$ aggregates lead to plaque formation, ${ }^{29}$ increasing evidence supports that the intraneuronal accumulation of $A \beta$ plays a critical role in $A D .^{1,2,21,22,30,31}$ Numerous studies have reported early intraneuronal accumulation of $A \beta$ in $A D$, Down syndrome, and FAD transgenic rodents. ${ }^{1-9,11,12,16}$ Intraneuronal $A \beta$ oligomerization ${ }^{16,23}$ and fibrillization have also been reported in FAD transgenic models. ${ }^{21,22}$ At the same time, immunohistochemical demonstration of intra- neuronal $A \beta$ is technically difficult, which has contributed to the slow acceptance for the role of this pool of $A \beta$ in $A D$. We set out, therefore, to better visualize $A \beta$ pathology in FAD transgenic mouse brains using immunofluorescence confocal microscopy combined with a novel HR-3D imaging technology to better delineate the progression of intraneuronal $A \beta$ pathology within the CA1 area of the hippocampus.

Now we use HR-3D imaging to clearly show that i) intraneuronal $A \beta$ accumulates at early ages before the formation of plaques. This intraneuronal $A \beta$ already forms fibrillar species; ii) within the CA1 region of the hippocampus, these intraneuronal fibrillar species were found within cell bodies of pyramidal and GABAergic neurons, processes, and synaptic structures, especially in postsynaptic compartments; iii) intraneuronal fibrillar $A \beta$ species were seen, even at the level of individual spines where such spines tended to appear less mushroom shaped and were associated with dystrophic enlargement; iv) remarkably, spines containing fibrillar $A \beta$ species could be seen right next to spines devoid of such species; v) within dendrites, increasing accumulation of fibrillar $A \beta$ species was associated with reduction in cytoskeletal proteins; and vi) fibrillar $A \beta$ species were seen piercing the cell membrane. In aggregate, these new data support a scenario in which plaques begin with deposits of intraneuronal $A \beta$, which then disrupts the cytoarchitecture, pierces the cell membrane, and forms the nidus for extracellular plaques.

\section{References}

1. Gouras GK, Tsai J, Naslund J, Vincent B, Edgar M, Checler F, Greenfield JP, Haroutunian V, Buxbaum JD, Xu H, Greengard P, Relkin NR: Intraneuronal Abeta42 accumulation in human brain. Am J Pathol 2000, 156:15-20

2. D'Andrea MR, Nagele RG, Wang HY, Peterson PA, Lee DH: Evidence that neurones accumulating amyloid can undergo lysis to form amyloid plaques in Alzheimer's disease. Histopathology 2001, 38:120134

3. Gyure KA, Durham R, Stewart WF, Smialek JE, Troncoso JC: Intraneuronal abeta-amyloid precedes development of amyloid plaques in Down syndrome. Arch Pathol Lab Med 2001, 125:489-492

4. Wirths O, Multhaup G, Czech C, Blanchard V, Moussaoui S, Tremp G, Pradier L, Beyreuther K, Bayer TA: Intraneuronal Abeta accumulation precedes plaque formation in beta-amyloid precursor protein and presenilin-1 double-transgenic mice. Neurosci Lett 2001, 306:116120

5. Mori C, Spooner ET, Wisniewsk KE, Wisniewski TM, Yamaguch H, Saido TC, Tolan DR, Selkoe DJ, Lemere CA: Intraneuronal Abeta42 accumulation in Down syndrome brain. Amyloid 2002, 9:88-102

6. Takahashi RH, Milner TA, Li F, Nam EE, Edgar MA, Yamaguchi H, Beal MF, Xu H, Greengard P, Gouras GK: Intraneuronal Alzheimer abeta42 accumulates in multivesicular bodies and is associated with synaptic pathology. Am J Pathol 2002, 161:1869-1879

7. Cataldo AM, Petanceska S, Terio NB, Peterhoff CM, Durham R, Mercken M, Mehta PD, Buxbaum J, Haroutunian V, Nixon RA: Abeta localization in abnormal endosomes: association with earliest Abeta elevations in AD and Down syndrome. Neurobiol Aging 2004, 25 : 1263-1272

8. Lord A, Kalimo H, Eckman C, Zhang XQ, Lannfelt L, Nilsson LN: The Arctic Alzheimer mutation facilitates early intraneuronal Abeta aggregation and senile plaque formation in transgenic mice. Neurobiol Aging 2006, 27:67-77 
9. Knobloch M, Konietzko U, Krebs DC, Nitsch RM: Intracellular Abeta and cognitive deficits precede beta-amyloid deposition in transgenic arcAbeta mice. Neurobiol Aging 2007, 28:1297-1306

10. Van Broeck B, Vanhoutte G, Pirici D, Van Dam D, Wils H, Cuijt I, Vennekens K, Zabielski M, Michalik A, Theuns J, De Deyn PP, Van der Linden A, Van Broeckhoven C, Kumar-Singh S: Intraneuronal amyloid beta and reduced brain volume in a novel APP T714I mouse model for Alzheimer's disease. Neurobiol Aging 2008, 29:241-252

11. Philipson O, Lannfelt L, Nilsson LN: Genetic and pharmacological evidence of intraneuronal Abeta accumulation in APP transgenic mice. FEBS Lett 2009, 583:3021-3026

12. Aho L, Pikkarainen M, Hiltunen M, Leinonen V, Alafuzoff I: Immunohistochemical visualization of amyloid-beta protein precursor and amyloid-beta in extra- and intracellular compartments in the human brain. J Alzheimers Dis 2010, 20:1015-1028

13. Belinson H, Kariv-Inbal Z, Kayed R, Masliah E, Michaelson DM: Following activation of the amyloid cascade, apolipoprotein E4 drives the in vivo oligomerization of amyloid-beta resulting in neurodegeneration. J Alzheimers Dis 2010, 22:959-970

14. Espana J, Gimenez-Llort L, Valero J, Minano A, Rabano A, Rodriguez-Alvarez J, LaFerla FM, Saura CA: Intraneuronal beta-amyloid accumulation in the amygdala enhances fear and anxiety in Alzheimer's disease transgenic mice. Biol Psychiatry 2010, 67:513-521

15. Gandy S, Simon AJ, Steele JW, Lublin AL, Lah JJ, Walker LC, Levey Al, Krafft GA, Levy E, Checler F, Glabe C, Bilker WB, Abel T, Schmeidler J, Ehrlich ME: Days to criterion as an indicator of toxicity associated with human Alzheimer amyloid-beta oligomers. Ann Neurol 2010, 68:220-230

16. Leon WC, Canneva F, Partridge V, Allard S, Ferretti MT, Dewilde A, Vercauteren F, Atifeh R, Ducatenzeiler A, Klein W, Szyf M, Alhonen L, Cuello AC: A novel transgenic rat model with a full alzheimer's-like amyloid pathology displays pre-plaque intracellular amyloid-betaassociated cognitive impairment. J Alzheimers Dis 2010, 20:113-126

17. Nunomura A, Tamaoki T, Tanaka K, Motohashi N, Nakamura M, Hayashi T, Yamaguchi H, Shimohama S, Lee HG, Zhu X, Smith MA, Perry G: Intraneuronal amyloid beta accumulation and oxidative damage to nucleic acids in Alzheimer disease. Neurobiol Dis 2010, 37: 731-737

18. Tomiyama T, Matsuyama S, Iso H, Umeda T, Takuma H, Ohnishi K, Ishibashi K, Teraoka R, Sakama N, Yamashita T, Nishitsuji K, Ito K, Shimada H, Lambert MP, Klein WL, Mori H: A mouse model of amyloid beta oligomers: their contribution to synaptic alteration, abnormal tau phosphorylation, glial activation, and neuronal loss in vivo. J Neurosci 2010, 30:4845-4856

19. Oddo S, Caccamo A, Shepherd JD, Murphy MP, Golde TE, Kayed R, Metherate R, Mattson MP, Akbari Y, LaFerla FM: Triple-transgenic model of Alzheimer's disease with plaques and tangles: intracellular Abeta and synaptic dysfunction. Neuron 2003, 39:409-421
20. Billings LM, Oddo S, Green KN, McGaugh JL, LaFerla FM: Intraneuronal Abeta causes the onset of early Alzheimer's disease-related cognitive deficits in transgenic mice. Neuron 2005, 45:675-688

21. Casas C, Sergeant N, Itier JM, Blanchard V, Wirths O, van der Kolk N, Vingtdeux V, van de Steeg E, Ret G, Canton T, Drobecq H, Clark A Bonici B, Delacourte A, Benavides J, Schmitz C, Tremp G, Bayer TA, Benoit P, Pradier L: Massive CA1/2 neuronal loss with intraneuronal and $\mathrm{N}$-terminal truncated Abeta42 accumulation in a novel Alzheimer transgenic model. Am J Pathol 2004, 165:1289-1300

22. Oakley H, Cole SL, Logan S, Maus E, Shao P, Craft J, GuillozetBongaarts A, Ohno M, Disterhoft J, Van Eldik L, Berry R, Vassar R: Intraneuronal beta-amyloid aggregates, neurodegeneration, and neuron loss in transgenic mice with five familial Alzheimer's disease mutations: potential factors in amyloid plaque formation. J Neurosci 2006, 26:10129-10140

23. Takahashi RH, Almeida CG, Kearney PF, Yu F, Lin MT, Milner TA, Gouras GK: Oligomerization of Alzheimer's beta-amyloid within processes and synapses of cultured neurons and brain. J Neurosci 2004, 24:3592-3599

24. Kayed R, Head E, Sarsoza F, Saing T, Cotman CW, Necula M, Margol L, Wu J, Breydo L, Thompson JL, Rasool S, Gurlo T, Butler P, Glabe CG: Fibril specific, conformation dependent antibodies recognize a generic epitope common to amyloid fibrils and fibrillar oligomers that is absent in prefibrillar oligomers. Mol Neurodegener 2007, 2:18

25. Li F, Calingasan NY, Yu F, Mauck WM, Toidze M, Almeida CG, Takahashi RH, Carlson GA, Flint Beal M, Lin MT, Gouras GK: Increased plaque burden in brains of APP mutant MnSOD heterozygous knockout mice. J Neurochem 2004, 89:1308-1312

26. Feng G, Mellor RH, Bernstein M, Keller-Peck C, Nguyen QT, Wallace M, Nerbonne JM, Lichtman JW, Sanes JR: Imaging neuronal subsets in transgenic mice expressing multiple spectral variants of GFP. Neuron 2000, 28:41-51

27. Dumont M, Wille E, Stack C, Calingasan NY, Beal MF, Lin MT: Reduction of oxidative stress, amyloid deposition, and memory deficit by manganese superoxide dismutase overexpression in a transgenic mouse model of Alzheimer's disease. FASEB J 2009, 23:2459-2466

28. Gouras GK, Tampellini D, Takahashi RH, Capetillo-Zarate E: Intraneuronal beta-amyloid accumulation and synapse pathology in Alzheimer's disease. Acta Neuropathol 2010, 119:523-541

29. Hardy J, Selkoe DJ: The amyloid hypothesis of Alzheimer's disease: progress and problems on the road to therapeutics. Science 2002, 297:353-356

30. Sheng JG, Bora SH, Xu G, Borchelt DR, Price DL, Koliatsos VE: Lipopolysaccharide-induced-neuroinflammation increases intracellular accumulation of amyloid precursor protein and amyloid beta peptide in APPswe transgenic mice. Neurobiol Dis 2003, 14:133-145

31. D'Andrea M, Nagele R: Morphologically distinct types of amyloid plaques point the way to a better understanding of Alzheimer's disease pathogenesis. Biotech Histochem 2010, 85:133-147 